\title{
The proportion of fine particles in pelleted diets does not affect the performance of slow-growing broiler chickens
}

\author{
La proporción de partículas finas en dietas peletizadas no afecta el desempeño del pollo de engorde de \\ lento crecimiento
Proporção de partículas finas em dietas peletizadas não afeta o desempenho de frangos de corte com crescimento lento

\begin{abstract}
Fabiana Ramos-Santos $^{1 * \text { (D); Deibity Alves-Cordeiro }}{ }^{\text {(D); Hyalo Batista-Santos }}{ }^{l}$ (D); Nayanne Rodrigues-Oliveira ${ }^{l}$ (D); Maura-Regina Sousa-Silval ${ }^{l}$; ; Cibele Silva-Minafral ${ }^{l}$ id; Júlia-Marixara Sousa-Silva ${ }^{2}$.
\end{abstract}

\footnotetext{
${ }^{1}$ Instituto Federal Goiano, Rio Verde, Brazil.

${ }^{2}$ Universidade Federal de Goiás, Goiânia, Brazil.
}

\section{To cite this article:}

Ramos-Santos F, Alves-Cordeiro D, Batista-Santos H, Rodrigues-Oliveira N, Sousa-Silva MR, Silva-Minafra C, SousaSilva JM. The proportion of fine particles in pelleted diets does not affect the performance of slow-growing broiler chickens. Rev Colomb Cienc Pecu 2021; 34(2): 84-94. DOI: https://doi.org/10.17533/udea.rccp.v34n2a01

\begin{abstract}
Background: The slow-growing chicken strains have particular nutritional and digestive needs, so they may digest pelleted feeds differently compared to commercial strains. Objective: To evaluate performance, digestibility, serum biochemical profile, digestive morphometry, carcass and cut yields of slow-growing broiler chickens fed pelleted feed with different concentrations of fine particles. Methods: A total of 180 slow-growing broiler chicks (Isa Label strain) aged one day were used. The animals were distributed in a completely randomized design with a 2 × 3 factorial scheme (Sex: male or female; Proportion of fine particles: 0,50 , or $100 \%$ ), with six repetitions of five birds/cage. The birds received water and feed ad libitum during the 28-day experimental period. Results: The proportion of fine particles did not affect the metabolic, digestive or productive variables evaluated. Males showed better overall performance, while females produced better thigh and liver yields. Conclusion: The proportion of fine particles in pelleted feeds did not affect productive or metabolic parameters. Thus, improving pellet quality for slow-growing broilers during the initial rearing phase may not be justified.
\end{abstract}

Keywords: alternative production; broiler chickens; digestibility; digestive development; feed fines; Isa Label; pelleted feed; performance; pellet quality; poultry; serum biochemistry.

Received: August 3, 2018; accepted: July 7, 2020

*Corresponding author. Rodovia Sul Goiana, Km 1, Zona Rural, Rio Verde, GO. 75901-000. Tel.: 55 (64) 3620-5600.

E-mail: fabiana.santos@ifgoiano.edu.br 


\section{Resumen}

Antecedentes: Los linajes de pollo de crecimiento lento presentan particularidades nutricionales y digestivas; por lo tanto, es posible que aprovechen los alimentos peletizados de manera diferente a los linajes comerciales. Objetivo: evaluar el desempeño, digestibilidad, perfil sérico bioquímico, morfometría digestiva, rendimiento de la carcasa y los cortes de pollos de engorde de crecimiento lento alimentados con raciones peletizadas con diferentes concentraciones de partículas finas. Métodos: Se utilizaron 180 pollitos machos y hembras, de crecimiento lento, de un día de edad, del linaje Isa Label. Los animales se distribuyeron en un diseño completamente aleatorizado y en un esquema factorial 2 x 3 (Sexo: macho y hembras; Proporción de partículas finas en la ración: 0,50 , y 100\%) con seis repeticiones de cinco aves/jaula. Las aves recibieron agua y ración ad libitum durante el período de prueba de 28 días. Resultados: la proporción de partículas finas no afectó las variables metabólicas, digestibles y productivas evaluadas. Los machos presentaron mejor desempeño, mientras que las hembras tuvieron mayor rendimiento de muslos e hígado. Conclusión: la proporción de partículas finas en raciones peletizadas no afecta los parámetros productivos y metabólicos. Por lo tanto, probablemente no se justifica mejorar la calidad del pelet para pollos de crecimiento lento en la fase inicial de cría.

Palabras clave: avicultura; bioquimica sérica; calidad del peletizado; desarrollo digestivo; digestibilidad; Isa Label; partículas finas; pollo de engorde; producción alternativa; ración peletizada; rendimiento.

\section{Resumo}

Antecedentes: linhagens de crescimento lento apresentam particularidades nutricionais e digestivas, portanto é possível que aproveitem os alimentos peletizados de maneira diferente das linhagens comerciais. Objetivo: avaliar o desempenho, digestibilidade dos alimentos, o perfil sérico bioquímico, a morfometria digestiva, rendimento de carcaça e cortes de frangos de corte com crescimento lento alimentados com rações peletizadas com diferentes concentrações de partículas finas. Métodos: Foram utilizados 180 pintos de corte, machos e fêmeas de crescimento lento, com um dia de idade, da linhagem Isa Label. Os animais foram distribuídos em delineamento inteiramente casualizado em esquema fatorial 2 x 3 (Sexo: macho e fêmeas; Proporção de partículas finas na ração: 0,50 , e $100 \%$ ) com seis repetições de cinco aves/gaiola. As aves receberam água e ração ad libtum durante o período experimental de 28 dias. Resultados: a proporção de partículas finas não afetou as variáveis metabólicas, digestórias e produtivas avaliadas. Os machos apresentaram melhor desempenho, enquanto as fêmeas tiverem maior rendimento de coxas e fígado. Conclusão: a proporção de partículas finas nas rações peletizadas não afetaram os parâmetros produtivos e metabólicos e, portanto, não justifica-se melhorias na qualidade de peletes de rações para frangos de crescimento lento na fase inicial de criação.

Palavras-chave: avicultura; bioquímica sérica; desempenho; desenvolvimento digestivo; digestibilidade; Isa Label; frangos de corte; partículas finas; produção alternativa; qualidade do peletes; ração peletizada. 


\section{Introduction}

The pelleting process is the agglomeration of small particles by mechanical pressure combined with moisture and heat. The advantages of this process on poultry performance are well known, but it is challenging for feed factories to produce good quality pellets. Physical quality of pellets depends on their ability to resist fragmentation and abrasion during storage and transport to the feeding troughs without disintegrating, thus preventing a high proportion of small particles called "fines" (Lowe, 2005; Amerah, 2007). Chickens given pelleted diets show higher feed consumption and conversion, hence greater weight gain (Freitas et al., 2008; Corzo et al., 2011; Abdollahi et al., 2013). However, if the proportion of fines is high, the benefits offered by pelleted diets can disappear when compared to mash feed (Klein, 1996; McKinney \& Teeter, 2004). The benefits of pelleted feeds for fastgrowing broilers have been demonstrated, but research is scarce on the effects of supplying pelleted feeds to slow-growing animals, especially when dealing with performance, metabolism, and nutrient digestibility. Breeding of slow-growing chickens in alternative systems -free-range or organic- is attracting more attention from farmers, not only as they require low initial investments but also due to higher sale price for the final product (Nascimento et $a l ., 2009)$. In these systems, the birds are reared in confinement during the initial phase, lasting between 28 and 42 days, and then have access to pasture areas where they reach slaughter weight at an age greater than 85 days (Fanatico et al., 2008; Fantico \& Born, 2002).

Slow-growing chicken strains have different growth rates, nutritional demands, and development of the digestive system compared to fast-growing strains reared industrially in total confinement (Santos et al., 2015a; Mendonça et al., 2008; Santos et al., 2005). Therefore, given the particularities of these free-ranging birds, they may transform pellet feeds into body mass differently than regular commercial strains.
The objective of this study was to evaluate performance, feed digestibility, serum biochemical profile, digestive morphometry, carcass and cut yields of slow-growing broiler chickens fed pelleted feeds with different concentrations of fines.

\section{Materials and Methods}

\section{Ethical considerations}

The study was approved by the Committee on Ethical Used of Animals at Instituto Federal Goiano (Rio Verde, Brazil) under protocol number 7662220217.

\section{Location and animals}

The metabolism and performance trial was conducted at the experimental aviary of Instituto Federal Goiano, Rio Verde Campus, in the state of Goiás, Brazil.

We used 180, one day old, slow-growing broiler chicks, males and females, of the Isa Label ${ }^{\circledR}$ strain. The initial weight of birds was $39.4 \pm 1.2$ g. The experiment lasted 28 days. The chicks were initially kept in a conventional shed, in galvanized $(0.9 \times 0.6 \times 0.4 \mathrm{~m})$ wire cages. Each cage was equipped with troughtype feeders and waterer. The average minimum and maximum temperature $\left({ }^{\circ} \mathrm{C}\right)$ and relative humidity (\%) values were $38.6 \pm 2.1{ }^{\circ} \mathrm{C} ; 61 \pm 1.8 \%$ and $18.2 \pm 1.4{ }^{\circ} \mathrm{C} ; 90 \pm 1.3 \%$, respectively.

\section{Experimental design}

The experimental design was completely randomized in a $2 \times 3$ factorial scheme (Sex: male or female; Proportion of fines: 0,50 , or $100 \%$ ), with six repetitions of five birds/cage. The initial pelleted feed was passed through a $2 \mathrm{~mm}$ mesh to obtain the experimental feed with the various fine proportions, and the portion retained was considered whole pellets, while the disintegrated grains that passed through were classified as fines. The experimental feed was formulated according to the nutritional requirements used by the local industry, adapted from the Brazilian Tables (2011) for broilers in starter and growing phase (1 to 21 days old) (Table 1). The feed was supplied 
by an integrator located in the Rio Verde region of Goiás, Brazil. The average particle diameters were $0.432,0.673$, and $0.918 \mathrm{~mm}$ for feeds with 100, 50 and $0 \%$ fines, respectively (Zanotto \& Bellaver, 1996).

Table 1. Composition and nutritional parameters of the experimental feed.

\begin{tabular}{|c|c|}
\hline Ingredients & $\%$ \\
\hline Corn & 73.950 \\
\hline Soybean meal & 22.368 \\
\hline Dicalcium phosphate & 1.609 \\
\hline Limestone & 0.926 \\
\hline Salt & 0.481 \\
\hline DL-methionine (99\%) & 0.146 \\
\hline L-lysine $(78.5 \%)$ & 0.168 \\
\hline L-threonine (98.5\%) & 0.001 \\
\hline Mineral supplement ${ }^{l}$ & 0.110 \\
\hline Vitamin supplement $^{2}$ & 0.110 \\
\hline Choline chloride (60\%) & 0.100 \\
\hline Colistin & 0.055 \\
\hline $\begin{array}{l}\text { Butyl-hydroxytoluene } \\
\text { (BHT) }\end{array}$ & 0.010 \\
\hline Nicarbazin & 0.005 \\
\hline Total & 100.000 \\
\hline \multicolumn{2}{|l|}{ Calculated values } \\
\hline $\begin{array}{l}\text { Metabolizable energy (kcal/ } \\
\mathrm{kg})\end{array}$ & 3.000 \\
\hline Crude protein (\%) & 22.132 \\
\hline Calcium (\%) & 0.819 \\
\hline Available phosphorus (\%) & 0.391 \\
\hline Sodium (\%) & 0.210 \\
\hline Digestible lysine (\%) & 0.847 \\
\hline Dig. Met + Cis $(\%)$ & 0.610 \\
\hline Digestible threonine (\%) & 0.550 \\
\hline Digestible tryptophan (\%) & 0.166 \\
\hline
\end{tabular}

${ }^{l}$ Mineral premix - Quantity per kg of feed: Mn, $77 \mathrm{mg}$; Fe, 55.0 mg; Zn, 71.5 mg; Cu, 11.0 mg; I, 1.10 mg; Se,0.330 mg.

${ }^{2}$ Vitamin premix - Quantity per kg of feed: vitamin A, 8,250 IU; vitamin D3, 2,090 IU; vitamin E, $31 \mathrm{IU}$; vitamin $\mathrm{K} 3,1.65 \mathrm{mg}$; vitamin B1, $2.20 \mathrm{mg}$; vitamin B2, $5.50 \mathrm{mg}$; vitamin B6, 3.08 mg; vitamin B12, 13 mcg; pantothenic acid, $11.0 \mathrm{mg}$; biotin, $0.077 \mathrm{mg}$; folic acid, $0.770 \mathrm{~g}$; nicotinic acid, $33.0 \mathrm{~g}$.

The birds received water and feed ad libitum. Animal performance was measured by weighing birds and feed at the start and end of the experiment. At 28 days of age, after a 12-hour fast, two birds per repetition were weighed and slaughtered by cutting the carotid artery and jugular vein. Carcass, abdominal fat, breasts, thigh, and drumstick were weighed (g) to determine carcass and cuts yield.

\section{Morphometry of digestive organs}

After evisceration, the gastrointestinal tract was measured from the esophagus to the large intestine connection with the cloaca $(\mathrm{cm})$. The relative weight of the digestive system (\%) (proventriculus and gizzard, pancreas, small intestine, large intestine, and liver) was obtained in proportion to the live weight of the bird.

\section{Biochemical profile of serum}

At slaughter, approximately $3 \mathrm{~mL}$ of blood was collected from each of the two birds per repetition. The samples were centrifuged at 5,000 rpm for 10 minutes. The serum samples were placed in Eppendorf micro-tubes and frozen. The serum levels of total proteins, cholesterol, and triglycerides were measured in triplicate with Doles commercial kits (Goiânia, Goiás, Brazil) using a Bel Photonics spectrophotometer model UV-MS1 (Piracicaba, São Paulo, Brazil).

\section{Assessment of nutritional efficiency}

Apparent metabolizable energy corrected for zero nitrogen balance (AMEn) and coefficients of apparent metabolizable dry matter (CMDM), gross energy (CMCE), and crude protein $(\mathrm{CMCP})$ were determined using the method of total excreta collection, as proposed by Sakomura and Rostagno (2016).

Excreta collections were performed on chicks at 14 to 18 days of age. The excreta were homogenized and dried in a forced-air oven at $55^{\circ} \mathrm{C}$ for 72 hours (ICNT-CA G-001/1 method). The excreta and feed were ground and analyzed for dry matter (ICNT-CA G-003/1 method) and nitrogen (ICNT-CA N-001/1 method) according to the techniques described by Detmann et al. (2012). Gross energy was determined with an 
IKA model C200 calorimeter (BioVera, Rio de Janeiro, RJ, Brazil). The AMEn and coefficients of apparent metabolization of nutrients were calculated by the equations described by Sakomura and Rostagno (2016).

\section{Statistical analysis}

Data were submitted to analysis of variance at 5\% probability using the ExpDes.pt statistical analysis package, available in the R-Project software. The Scott-Knott test was used to compare differences between means.

\section{Results}

No significant interaction was observed between proportion of fines and sex for performance variables, carcass yield, digestive organ biometry, serum biochemical profile, and nutritional efficiency (Tables 2, 3, 4, 5 and 6).

Table 2. Performance of slow-growing male and female broilers fed different proportions of fines during the first 28 days of age.

\begin{tabular}{lcccc}
\hline & MW (kg) & FC (kg) & WG (Kg) & FConv (kg:kg) \\
\hline Proportion of fines (\%) & & & & \\
\hline 0 & 0.841 & 1.482 & 0.803 & 1.861 \\
50 & 0.829 & 1.472 & 0.791 & 1.863 \\
100 & 0.786 & 1.421 & 0.748 & 1.903 \\
\hline Sex & & & $1.828^{\mathrm{b}}$ \\
\hline Males & $0.853^{\mathrm{a}}$ & 1.482 & $0.815^{\mathrm{a}}$ & $1.924^{\mathrm{a}}$ \\
\hline Females & $0.784^{\mathrm{b}}$ & 1.434 & $0.747^{\mathrm{b}}$ & \\
\hline Probabilities ${ }^{l}$ & & & 0.6519 \\
\hline Fines (F) & 0.074 & 0.2765 & 0.075 & 0.0286 \\
Sex (S) & 0.0018 & 0.1535 & 0.0019 & 0.449 \\
F x S & 0.9611 & 0.482 & 0.9641 & 6.69 \\
\hline CV (\%) & 7.34 & 6.74 & 7.71 & \\
\hline
\end{tabular}

${ }^{1}(\mathrm{p}<0.05)$; ${ }^{2}$ Coefficient of variation; MW: Mean weight; FC: Feed consumption; WG: Weight gain; FConv: Feed conversion. Different superscript letters $\left({ }^{\mathrm{a}, \mathrm{b}}\right)$ in the same column indicate different means according to the Scott-Knott test at $5 \%$ probability.

Table 3. Yield of carcass and cuts of slow-growing male and female broilers fed different proportions of fines during the first 28 days of age.

\begin{tabular}{lccccc}
\hline Yield (\%) & Fat & Breast & Thighs & Drumstick & Carcass \\
\hline Proportion of fines (\%) & & & & & \\
\hline 0 & 1.63 & 19.62 & $10.13^{\mathrm{b}}$ & 11.06 & 71.66 \\
50 & 1.47 & 19.84 & $10.69^{\mathrm{a}}$ & 10.89 & 70.96 \\
100 & 1.59 & 19.69 & $10.58^{\mathrm{a}}$ & 10.73 & 70.94 \\
\hline Sex & & & & \\
\hline Males & 1.52 & 19.56 & 10.51 & $10.51^{\mathrm{b}}$ & 71.89 \\
Females & 1.61 & 19.87 & 10.43 & $11.28^{\mathrm{a}}$ & 70.45 \\
\hline Probabilities ${ }^{1}$ & & & & \\
\hline Fines (F) & 0.7438 & 0.9300 & 0.0269 & 0.7159 & 0.8399 \\
Sex (S) & 0.6311 & 0.5123 & 0.6213 & 0.0284 & 0.2079 \\
F x S & 0.3955 & 0.8164 & 0.1403 & 0.2057 & 0.9511 \\
\hline $\mathrm{CV}(\%)^{2}$ & 23.7300 & 7.110 & 4.880 & 9.210 & 4.710 \\
\hline
\end{tabular}

${ }^{1}(p<0.05) ;{ }^{2}$ Coefficient of variation; Different superscript letters $\left({ }^{a, b}\right)$ within the same column indicate different means according to the Scott-Knott test at $5 \%$ probability. 
Greater mean weight (MW), weight gain (WG) and better feed conversion (FConv) were observed for male compared to female birds. However, the proportion of fines did not affect chicks during the initial rearing phase (Table 2).

Relative weight of the liver was higher for females than males (Table 4). The proportion of fines did not affect morphometry of digestive organs.

No significant correlation was found between proportion of fines in feed and sex of the birds for serum cholesterol, triglycerides, and total proteins at 28 days of age (Table 5).

Table 4. Performance of slow-growing male and female broilers fed different proportions of fines during the first 28 days of age.

\begin{tabular}{|c|c|c|c|c|c|c|}
\hline & \multicolumn{6}{|c|}{ Relative weight (\%) } \\
\hline & GIT (m) & SI & LI & Prov+Gizz & Pancreas & Liver \\
\hline \multicolumn{7}{|c|}{ Proportion of fines (\%) } \\
\hline 0 & 1.24 & 3.27 & 0.79 & 3.21 & 0.31 & 2.34 \\
\hline 50 & 1.25 & 3.39 & 0.94 & 3.17 & 0.32 & 2.39 \\
\hline 100 & 1.22 & 3.27 & 0.82 & 3.26 & 0.33 & 2.18 \\
\hline \multicolumn{7}{|l|}{ Sex } \\
\hline Males & 1.24 & 3.35 & 0.83 & 3.21 & 0.33 & $2.42^{\mathrm{a}}$ \\
\hline Females & 1.24 & 3.28 & 0.88 & 3.22 & 0.31 & $2.18^{\mathrm{b}}$ \\
\hline \multicolumn{7}{|c|}{ Probabilities $^{1}$} \\
\hline Fines & 0.8166 & 0.5278 & 0.1004 & 0.8495 & 0.7319 & 0.1452 \\
\hline Sex & 0.9959 & 0.4652 & 0.4126 & 0.9348 & 0.3814 & 0.0085 \\
\hline $\mathrm{F} \times \mathrm{S}$ & 0.7057 & 0.3815 & 0.6749 & 0.3882 & 0.0847 & 0.0980 \\
\hline $\mathrm{CV}(\%)^{2}$ & 7.74 & 8.90 & 20.38 & 11.30 & 22.08 & 11.28 \\
\hline
\end{tabular}

${ }^{1}$ (p<0.05); ${ }^{2}$ Coefficient of variation; GIT: Gastrointestinal tract; SI: Small intestine; LI: Large intestine; Prov+Gizz: Proventriculus plus gizzard. Different superscript letters $\left({ }^{a}, b\right)$ within the same column indicate different means according to the Scott-Knott test at $5 \%$ probability.

Table 5. Serum profile of slow-growing male and female broilers fed different proportions of fines during the first 28 days of age.

\begin{tabular}{lccc}
\hline & Cholesterol (mg/dL) & Triglycerides (mg/dL) & Total Proteins (g/dL) \\
\hline Proportion of fines (\%) & & & \\
\hline 0 & 178.90 & 126.22 & 3.87 \\
50 & 176.61 & 146.83 & 4.00 \\
100 & 197.12 & 133.34 & 4.16 \\
\hline Sex & & & 4.03 \\
\hline Males & 190.62 & 132.24 & 3.98 \\
Females & 177.78 & 138.55 & \\
\hline Probabilities ${ }^{1}$ & & & 0.4463 \\
\hline Fines (F) & 0.7748 & 0.2433 & 0.7742 \\
Sex (S) & 0.6183 & 0.5397 & 0.6428 \\
F x S & 0.5881 & 0.6892 & 13.780 \\
\hline CV $(\%)^{2}$ & 21.6100 & 11.970 & \\
\hline
\end{tabular}

${ }^{1}(\mathrm{p}<0.05) ;{ }^{2}$ Coefficient of variation. 
The proportion of fines and sex of birds did not affect the AMEn and coefficients of apparent metabolization of nutrients in broilers at 14 to 18 days of age (Table 6 ).

Table 6. Energy and nutritional metabolizability of slow-growing male and female broilers fed different proportions of fines during 28 days of age ${ }^{l}$.

\begin{tabular}{lcccc}
\hline & AMEn (Kcal/g) & CMCE (\%) & CMDM (\%) & CMCP (\%) \\
\hline Proportion of fines (\%) & & & & \\
\hline 0 & 3.162 & 86.07 & 82.76 & 39.97 \\
50 & 3.150 & 85.78 & 83.08 & 42.52 \\
100 & 3.183 & 86.71 & 83.71 & 47.06 \\
\hline Sex & & & 43.24 \\
\hline Males & 3.171 & 86.36 & 83.41 & 43.29 \\
Females & 3.159 & 86.02 & 82.96 & 0.3406 \\
\hline Probabilities & & & 0.8805 \\
\hline Fines & 0.7673 & 0.7671 & 0.8121 & 0.9994 \\
Sex & 0.7572 & 0.7523 & 0.7137 & 6.69 \\
F x S & 0.7662 & 0.7685 & 0.6188 & 7.71 \\
\hline CV (\%)
\end{tabular}

${ }^{I}$ Data in natural matter: Apparent metabolizable energy corrected for zero nitrogen balance (AMEn) and coefficients of apparent metabolizable dry matter (CMDM), gross energy $(\mathrm{CMCE})$ and crude protein $(\mathrm{CMCP}) ;{ }^{2}(\mathrm{p}<0.05)$; ${ }^{3}$ Coefficient of variation.

\section{Discussion}

A difference in performance between male and female broilers was expected. According to Santos et al., (2005), growth rate of males and females of slow-growing strains is similar up to 21 days of age, and starting at 28 days male broilers grow faster, indicating greater efficiency. Api et al., (2017), working with three fast-growing strains (Cobb, Hubbard and Ross) also observed greater development in males than females in the third week of life. According to them, animal growth is determined by growth of the nervous system, bone, muscle and adipose tissues. Since females reach puberty sooner than males, growth of the adipose tissue occurs sooner, in detriment to muscle tissue, causing lower weight gain. It is known that fast-growing broilers fed diets with high-quality pellets perform better than those receiving mash feeds due to a greater ease of feeding, besides lower waste of feed and less energy expenditure during consumption (Abdollahi, 2011; Corzo et al., 2011; Zohair et al., 2012). However, that effect was not observed in the present study with Isa Label strain. Slow-growing birds have specific traits, and their slower growth means lower nutritional demands compared to commercial broiler strains, in addition to greater weight of the gastrointestinal tract and organs with less occurrence of bone problems (Santos et al., 2005; Mendonça et al., 2008; Santos et al., 2015a). These peculiar characteristics influence the nutritional efficiency and performance of these strains in relation to fast-growing birds.

Regarding carcass characteristics, as verified in the present study, Lara et al., (2008), investigating on mash and pellet feeds, found that treatments did not influence yield of cuts and carcass. Similarly, López \& Baião (2002) did not find differences when comparing carcasses of broilers slaughtered at 43 days of age fed mash or pellet diets.

Typically, consumption of good-quality pellets can influence the development of digestive organs, especially the size and weight of the gizzard. The study by Freitas et al. (2008) -working with mash, pellet, and ground feedsdid not find an effect concerning the physical form of feed on the relative weight of digestive 
organs, except for the gizzard, which was larger in the birds receiving mash feeds. The mechanism by which the physical characteristics of the feed affect gizzard size is not entirely understood. A leading hypothesis is that lower consumption of pelleted feed in relation to mash feed can cause lower passage rate. Thus, lower muscular stimulation occurs by the mechanical action promoted by the presence of feed in this organ (Engberg et al., 2002; López \& Baião, 2004). Therefore, the lack of effects of feed quality on consumption in this study can explain the similar relative weight of digestive organs, especially the gizzard. On the other hand, there is evidence that, irrespective of the physical form of feed, slow-growing birds have lower carcass weight and greater relative weight of digestive organs than conventional bird strains (Santos et al., 2015a; Santos et al., 2005). Studies have related greater weight of the gastric compartment (proventriculus + gizzard) to better extraction of energy from feed (Rougiére et al., 2009; Verdal et al., 2010). Therefore, high relative weight of the proventriculus and gizzard in slow-growing birds can enhance the energy extraction and consequently withdraw the positive effects pelleted feed may have concerning digestive development and nutrient digestibility, as seen in this study.

We stress that the increased performance of birds associated with consumption of pelleted feeds is mainly due to the greater ability for feeding, resulting in less energy expenditure for this activity, along with improved digestibility of nutrients-like starch and proteins- as well as energy utilization (Moran Jr., 1987; McCraken, 2002). These positive effects on nutrient digestibility are attributed to the mechanical action, temperature, and moisture used during the pelleting process, which among other factors help to breakdown amylose and amylopectin granules and promote changes in the tertiary structure of proteins, facilitating the enzymatic action (López, 2007). Therefore, although feeds with high proportions of fines can require greater energy expenditure for consumption, they benefited from the thermal processing, which can explain the absence of effects of diets with 0,50 , and $100 \%$ fines on nutritional efficiency and overall performance observed in this study. Additionally, according to Santos et al. (2015b), Isa Label birds are more efficient in extracting energy from cornmeal and soybean meal than birds of the Cobb 500 strain. Therefore, the results obtained in this study indicate that due to a greater nutritional efficiency of slow-growing broilers, pellet quality was not a limiting factor in terms of performance during the initial rearing phase.

Santos et al. (2015a), in a study investigating the serum biochemical constituents of slowgrowing broilers aged 21 days and given mash feed, observed worse results than those obtained in the present study for cholesterol (173.63 $\mathrm{mg} \mathrm{dL}^{1}$ ), and better for triglycerides and total proteins (244.35 and $5.72 \mathrm{mg} \mathrm{dL}^{1}$ ). Laboratory analyses of blood samples are used to monitor broiler health by enabling diagnosis and subsequent treatment of diseases. However, few studies have been published on the levels of serum constituents to establish references for industrially-bred birds. Additionally, studies presenting serum biochemical parameters for slow-growing strains are also limited. One of them was conducted by Barbosa et al. (2011), who postulated that age, strain, nutrition, and environmental conditions can affect serum parameters. Thus, the results obtained in the present study can serve as a reference for the Isa Label strain at 28 days of age fed pelleted feeds.

In conclusion, pellet rations with high proportion of fines do not affect the performance or metabolic parameters of slow-growing birds; therefore, the use of pellet rations for these strains in the initial phase is not justified.

\section{Declarations}

\section{Funding}

Instituto Federal de Educação, Ciência e Tecnologia Goiano (IF Goiano, Rio Verde - GO - Brazil) provided all the necessary materials for conducting this study. The experimental ration was donated by Brasil Foods S.A - Brazil. 


\section{Authors contribution}

Fabiana Ramos Santos elaborated the study, including the experimental design, paper reviewing and edition.

Deibity Alves Cordeiro managed the project, collected the data and revised the paper. Hyalo Batista Santos managed the project and collected the data.

Nayanne Rodrigues Oliveira collected the data and reviewed the paper.

Maura Regina Sousa Silva collected the data.

Cibele Silva Minafra was responsible for reading the text and editing the paper.

Júlia Marixara Sousa Silva revised the paper.

\section{Conflicts of interest}

The authors declare they have no conflicts of interest with regard to the work presented in this report.

\section{References}

Abdollahi MR. Influence of feed processing on the performance, nutrient utilisation and gut development of poultry and feed quality. Thesis - Massey University 2011: $195 f$.

Abdollahi MR, Ravindran V, Svihus B. Influence of grain type and feed form on performance, apparent metabolisable energy and ileal digestibility of nitrogen, starch, fat, calcium and phosphorus in broiler starters. Anim Feed Sci Tech 2013; 186(3-4):193-203. DOI: https://doi.org/10.1016/j.anifeedsci.2013.10.015

Amerah AM, Ravindran V, Lentle RG. Feed particle size: Implications on the digestion and performance in poultry. Worlds Poult Sci J 2007; 63(3):439-451. DOI: https://doi.org/10.1017/S0043933907001560
ApiI, TakahashiSE, MendesAS, Paixão SJ, Refati R, Restelatto R. Efeito da sexagem e linhagens sobre o desempenho e rendimento de carcaça de frangos de corte. Ciênc anim bras 2017; 18:1-10. DOI: https://doi.org/10.1590/1089-6891v18e-32691

Barbosa TS, Mori CK, Polônio LB, Ponsano EHG, Ciarlini PC. Perfil bioquímico sérico de galinhas poedeiras na região de Araçatuba, SP. Semin Cienc Agrar 2011;32(4):1583-1588. DOI: https://doi.org/10.5433/1679-0359.2011v32n4p1583

Corzo A, Mejia L, Loar IIRE. Effect of pellet quality on various broiler production parameters. J Appl Poult 2011; 20:68-74. DOI: https://doi:10.3382/japr.2010-00229

Detmann E, Souza MA, Valadares Filho SC, Queiroz AC, BerchiellI TT, Saliba EOS, Cabral LS, Pina DS, Ladeira MM, Azevedo JAG. Métodos para análise de alimentos. Visconde do Rio Branco: Suprema, 2012. 214p.

Engberg RM, Hedemann MS, Jensen BB. The influence of grinding and pelleting of feed on the microbial composition and activity in the digestive tract of broiler chickens. $\mathrm{Br}$ Poult Sci 2002; 44:569-579. DOI: https://doi.org/10.1080/0007166022000004480

Fanatico AC, Pillai PB, Hester PY, Falcone C, MenchJA, Owens CM,EmmertJL. Performance, livability, and carcass yield of slow- and fastgrowing chicken genotypes fed low-nutrient or standard diets and raised indoors or with outdoor access. Poult Sci 2008; 87:1012-1021. DOI: https://doi.org/10.3382/ps.2006-00424

Fanatico AC, Born H. Label rouge: pasturebased poultry production in France. ATTRA A National Sustainable Agriculture Assistance Program 2002; [Accessed in May 2018] URL: https://attra.ncat.org/attra-pub/download.php?id=224 
Freitas ER, Sakomura NK, Dahlke F, Santos FR, Barbosa NAA. Desempenho, eficiência de utilização dos nutrientes e estrutura do trato digestório de pintos de corte alimentados na fase pré-inicial com rações de diferentes formas físicas. Rev Bras Zootec 2008; 37:73-78. DOI: doi.org/10.1590/S1516-35982008000100010

Klein $\mathrm{CH}$. Efeito da forma física e do nível de energia da ração sobre o desempenho, a composição de carcaça e a eficiência de utilização da energia metabolizável consumida por frangos de corte. 1996. 97f. Dissertação de Mestrado Universidade Federal do Rio Grande do Sul.

Lara LJC, Baião NC, Rocha JSR, Lana AMQ, Cançado SV, Fontes DO, Leite RS. Influence of physical form of ration and lineage on the performance and yield of broiler cuts. Arq Bras Med Vet Zootec 2008; 60(4):970-978. DOI: https://doi.org/10.1590/S0102-09352008000400028

López CAA, Baião NC. Effects of whole and separate grinding of feed ingredients and physical form of ration on performance of broiler chickens. ArqBrasMedVetZootec 2002; 54:189-195.DOI: https://doi.org/10.1590/S0102-09352002000200010

López CAA, Baião NC. Effects of particle size and physical form of ration on performance, carcass yield and weight of digestive organs of broiler chickens. Arq Bras Med Vet Zootec 2004; 56:214-221. DOI: https://doi.org/10.1590/S0102-09352004000200012

López CAA, Baião NC, Lara LJC, Rodriguez NM, Cançado SV. Effects of physical form of ration on feed digestibility and performance of broiler chickens. Arq Bras Med Vet Zootec 2007; 59(4):1006-1013. DOI: https://doi.org/10.1590/S0102-09352007000400029

Lowe R. Judging pellet stability as part of pellet quality. Feed Tech 2005; 9(2); [Accessed in september 2019] URL: www.allaboutfeed. net/Processing/Pelleting/2005/3/Judgingpellet-stability-as-part-of-pellet-quality$\underline{\mathrm{AAF} 010181 \mathrm{~W} /}$
McCracken KJ. Effects of physical processing on the nutritive value of poultry diets. In: Poultry feedstuffs: Supply, composition and nutritive value. Cabi Publishing 2002; 16:301-316. DOI: https://doi.org/10.1079/9780851994642.0301

McKinney LJ, Teeter RG. Predicting effective caloric value of nonnutritive factors: I. pellet quality and II. prediction of consequential formulation dead zones. Poult Sci 2004; 83:1165-1174. DOI: https://doi.org/10.1093/ps/83.7.1065

Mendonça MO, Sakomura NK, Santos FR, Freitas ER, Fernandes JBK, Barbosa NAA. Metabolizable energy levels for slow growth male broilers raised in semi confined system. R Bras Zootec 2008; 37(8):1433-1440. DOI: https://doi.org/10.1590/S1516-35982008000800014

Moran Jr ET. Pelleting: affects feed and its consumption. Poult Sci 1987; 5:30-31.

Rougiére N, Gomes J, Mignon-Grasteau $\mathrm{S}$, Carré B. Effects of diet particle size on digestive parameters in $\mathrm{D}+$ and $\mathrm{D}-$ genetic chicken lines selected for divergent digestion efficiency. Poult Sci 2009; 88:1206-1215. DOI: https://doi.org/10.3382/ps.2008-00408

Sakomura NK, Rostagno HS. Métodos de pesquisa em nutrição de monogástricos. 2nd ed. Jaboticabal: FUNEP, 2016.

Santos AL, Sakomura NK, Freitas ER, Sá Fortes CML, Carrilho ENVM, Fernandes JBK. Growth, Performance, Carcass Yield and Meat Quality of Three Broiler Chickens Strains. Rev Bras Zootec 2005; 34(5):1589-1598. DOI: https://doi.org/10.1590/S1516-35982005000500020

Santos FR, Stringhini JH, Freitas NF, Minafra CS, Oliveira PR, Duarte EF, Guimarães GS. Morphological and morphometric aspects of the digestive apparatus, serum biochemical measures and activity of pancreatic enzymes of slow- and fast-growing broilers. Rev Bras Ci Ag 2015; 10(2):322-327. DOI: https://doi.org/10.5039/agraria.v10i2a4370 
Santos FR, Stringhini JH, Oliveira PR, DuarteEF, Minafra CS, Café MB. Values of Metabolizable Energy and Metabolization of Nutrients for Slow- and Fast-growing Birds at Different Ages. Br Poult Sci 2015; 17(4):517-522. DOI: https://doi.org/10.1590/1516-635X1704517-522

Verdal H, Mignon-Grasteau S, Jeulin C, Le Bihan-Duval E, Leconte M, Mallet S, Martin C, Narcy A. Digestive tract measurements and histological adaptation in broiler lines divergently selected for digestive efficiency. Poult Sci 2010; 89:1955-1961. DOI: https://doi.org10.3382/ps.2010-813

Zohair GAM, Al-Maktari GA, Amer MA. Comparative effect of mash and pellet feed on broiler performance and ascites at high altitude (Field Study). Global Veterinaria 2012; 9:154-159. DOI: https://doi.org/10.5829/idosi.gv.2012.9.2.63156 